\title{
Anti-HIV Activity of Phytosterol Isolated from Aerva lanata Roots
}

\author{
Rajendra Prasad Gujjeti and Estari Mamidala*
}

\begin{abstract}
Background: AIDS in humans, which is caused by the HIV remains among the leading causes of death worldwide. Objective: The study was undertaken to investigate the HIV-RT inhibitory activity of Phytotesrols extracted from roots of Aerva lanata. Methodology: Sequential maceration method was performed for preparation of extracts using hexane, chloroform, ethyl acetate, acetone and methanol solvents. RetroSys HIV-1 RT (Innovagen, Sweden) kit was used to determine the HIV-RT inhibitory activity of all solvents extracts. Results \& Discussion: All extracts showed significant inhibitory activity. Chloroform extracts shows highest inhibition of recombinant HIV-RT $(89.0 \%)$ at 2 and $\mathrm{mg} / \mathrm{ml}$ concentration. Phytosterols isolated from chloroform extracts. These results were remarkable and can be used to develop a new drug for HIV treatment or other infectious diseases caused by the pathogenic micro-organisms, for which plant sterols may play a distinctive role. Conclusion: Further work is in progress to evaluate the advanced spectroscopic studies are required for the structural elucidation, identification and characterization of the active compound from this plant.

Key words: Aerva lanata, HIV-1, Phytosterols, Reverse transcriptase, Characterization, Structural elucidation.
\end{abstract}

Rajendra Prasad Gujjeti and Estari Mamidala*

Department of Zoology, Infectious Diseases and Metabolic Disorders Research Lab, Kakatiya University, Warangal-506009, INDIA

\section{Correspondence}

Estari Mamidala,

Department of Zoology, Infectious Diseases \& Metabolic Disorders Research Lab, Kakatiya University, Warangal-506009, Telangana, INDIA.

Phone no: 9848309231

E-mail: estari08@gmail.com

History

- Submission Date: 04-07-2016;

- Review completed: 22-08-2016

- Accepted Date: 10-09-2016.

DOI : 10.5530/pj.2017.1.19

Article Available online

http://www.phcogj.com/v9/i1

Copyright

(C) 2016 Phoog.Net. This is an openaccess article distributed under the terms of the Creative Commons Attribution 4.0 International license.

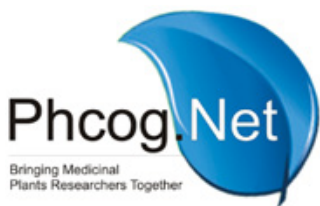

the regular normal functioning cells, thereby reducing the side effects. The present study was to evaluate the HIV reverse transcriptase inhibitory activity of phytosterol of Aerva lanata roots. fection continues to spread throughout the world despite a downward trend of HIV new infections, an estimated 35.3 million people are currently living with this virus. ${ }^{1}$ Now a days, a large variety of natural products from medicinal plants, such as alkaloids, phytosterols, flavonoids, lignans, polysaccharides and so on, have been found to inhibit unique enzymes and proteins crucial to the life cycle of HIV, including the reverse transcription process, virus entry, the integrase or protease..$^{2-4}$ Herbal medicine is now globally accepted as a legal, alternative system of therapy for treatment and cure of various diseases and physiological conditions in traditional treatments in the form of pharmaceuticals. ${ }^{5}$ Previous investigations established that different medicinal plant extracts inhibit HIV reverse transcriptase in non-specific manner. ${ }^{6,7}$ Phytochemical analysis conducted on the plant extracts revealed the presence of constituents which are known to exhibit medicinal as well as physiological activities. ${ }^{8}$ The medicinal value of plants lies in some chemical substances that have a definite physiological action on the human body. Different phytochemicals have been found to possess a wide range of activities. ${ }^{9}$ Therefore, screening of potential anti-HIV agents from medicinal plants may be a rapid and effective way for drug discovery. However, drug toxicity, drug resistance, adverse drug-drug interactions, and accompanying poor patient adherence are still the major factors leading to treatment failure. ${ }^{10}$ There is still an acute need for less toxic and more potent HIV drugs and continues be the concern. The aim of research in HIV drug development is to find new drugs that are specific to HIV, or to develop a method that alters the nature of the drug administered such that it acts only on the target cells and not

\section{MATERIAL AND METHODS}

\section{Plant collection}

Plant was selected for this study is based on its traditional medicinal use. ${ }^{11}$ Aerva lanata roots were collected from the Chintur mandal, Khammam district of Telangana, India, in the month of September 2012. The plant voucher specimen identification was done with the help of taxonomist Prof. Vastsavaya. S. Raju Department of Botany Kakatiya University, Warangal and the same was deposited at Infectious Diseases \& Metabolic Disorders Research Lab, Department of Zoology, Kakatiya University, Warangal.

\section{Preparation of plant extract}

After collection of selected medicinal plant material sample was dried at room temperature until they were free from moisture. The selected part of plant subjected to size reduction to get coarse powder was then stored in a clean dry air tight container. The air dried powder was subjected to sequential maceration method used by different solvents (hexane, chloroform, ethyl acetate, acetone, and methanol etc ;) for seven days. The extract was filtered mass was obtained and it was finally dried at low room temperature under pressure in a rotary vacuum evaporator (Thermotech, buchi type model th-012).

\section{HIV-1 Reverse Transcriptase Inhibition} Assay

The HIV reverse transcriptase enzyme inhibition due to each extract was deter- 
mined using HIV RT inhibition assay by using of Retro Sys HIV-1 RT activity kit (Innovagen, Sweden). To determining RT activity on inhibiting substances that are to be analysed are serially diluted. The diluted substances are then added to a plate with reaction mixture. After 30 minutes of pre-incubation at $33^{\circ} \mathrm{C}$, the reaction is started by the addition of a standardised amount of RT. The RT will now incorporate BrdUMP depending on the level of inhibition. The product is quantified by the addition of the RT Product Tracer which binds to the incorporated BrdUMP. After removing excess tracer the amount of bound tracer is determined by an alkaline phosphatase/pNPP colour reaction. ${ }^{1}$ After correction for background signal, the measured residual RT activity for each substance dilution is calculated as a percentage of the measured RT activity in absence of inhibiting substances. Plot the percentage of residual RT activity against the concentrations of the substance dilutions for each of the tested substances. AZT (Azidothymidine) was used as control. The inhibitory effect of each substance is expressed by RT activity and is determined with the aid of the obtained graph. All fractions were selected for anti-HIV activity. The percentage inhibition of HIV-1 RT was calculates as,

Inhibition $(\%)=[($ A control $-A$ sample $) / A$ control $] \times 100$

Where, A is Optical Density (OD).

\section{Isolation of active compound from Aerva lanata crude extract}

\section{Thin layer chromatographic studies}

TLC as per conventional one dimensional ascending method using silica gel 60F254, 7×6 cm (Merck) were cut with ordinary household scissors. Plate markings were made with soft pencil. Glass capillaries were used to spot the sample on TLC volume $1 \mu$ by using capillary at distance of $1 \mathrm{~cm}$ at 1 track.

To find which solvent system is suitable for separation of compounds, the five solvent systems were selected. These are solvent system I (hexane: acetic acid 9:1), solvent system II (hexane: ethyl acetate: acetic acid 5:4:1), solvent system III (hexane: ethyl acetate: acetic acid 4:4:2), solvent system IV (hexane: ethyl acetate: acetic acid 3:6:1) and solvent system V (hexane: ethyl acetate: acetic acid 2:7:1). The chloroform extract was applied on pre-coated TLC plates and developed in TLC chamber. The developed plates were air dried and iodine vapors were used to detect the bands on the TLC plates. In this study, the TLC chromatograms were developed in five eluent systems of different polarity. Finally solvent system V (hexane: ethyl acetate: acetic acid 2:7:1) was selected for column chromatography. The movement of the active compound was expressed by its retention factor $\left(\mathrm{R}_{\mathrm{f}}\right)$, values were calculated for different samples by following equation:

$\mathrm{R}_{\mathrm{f}}=$ Distance travelled by the solute/Distance travelled by the solvent front TLC plates

\section{Column chromatographic studies}

The column can be prepared using a column chromatography flask. Glass wool was inserted at the bottom of the flask to prevent the silica from escaping the column. The mixture of hexane: ethyl acetate: acetic acid in the volume ratio $(2: 7: 1)$ used in TLC was used as the mobile phase. $4 \mathrm{gm}$ of plant active crude extract was added to $8 \mathrm{gm}$ of silica gel. This was then added to a packed column (silica gel packed with hexane which is the least polar in the solvent mixture). The selected mobile phase (hexane: ethyl acetate: acetic acid 2:7:1) was continuously poured to the top with the aid of a dropper. The bottom outlet of the column was opened, allowing the eluent to flow through the column. As the eluent passed down the column, the compound fraction moved down the column. The separated fraction flowed out of the column where the different eluates were
Table 1: Extractive values of different extracts of Aerva lanata roots

\begin{tabular}{cccc}
\hline Solvent & Color of extract & $\begin{array}{c}\text { Yield of the } \\
\text { extract (in gm) }\end{array}$ & $\begin{array}{c}\text { Percentage yield } \\
(\% \mathrm{w} / \mathrm{w})\end{array}$ \\
\hline Hexane & White & 5.020 & $2.51 \%$ \\
Chloroform & Light brown & 4.080 & $2.04 \%$ \\
Ethyl acetate & Light brown & 2.750 & $1.37 \%$ \\
Acetone & Light brown & 1.720 & $0.86 \%$ \\
Methanol & Dark brown & 3.750 & $1.85 \%$ \\
\hline
\end{tabular}

collected in separate test tubes. This was repeated until all the dissolved extract was adsorbed on to the silica gel.

The total of 24 fractions was collected within $6 \mathrm{hr} 15$ min each fraction containing $5 \mathrm{ml}$. All fractions were concentrated under rotary reduced pressure evaporation rotating at $100 \mathrm{rpm}$ and with water bath at $40^{\circ} \mathrm{C}$ (Thermotech, buchi type model th-012). All fractions were spotted on TLC plate and on visualized using iodine vapors. The $R_{f}$ values of 24 fractions were recorded and same $\mathrm{R}_{\mathrm{f}}$ value fractions were pooled. 24 fractions were reduced in to three categories after pooling.

Anti-HIV activity of these three fractions was done by Retro Sys HIV-1 RT activity kit (Innovagen, Sweden). Active fractions were tested for TLC to detect the purity. For further purification this active fraction processed to column chromatography by using solvent system chloroform and ethyl acetate in the ratio of 9:1. Six fractions were collected and pooled based on similar $\mathrm{R}_{\mathrm{f}}$ values. Six fractions were reduced in to three fractions. Three fractions tested for anti-HIV activity. Active fraction is selected for further purification process. Column chromatography was done on above mentioned active fraction by using solvent system chloroform and ethyl acetate in the ratio 8:2. Finally single spot was obtained in TLC of active fraction.

\section{Phytochemical screening of active compound}

Qualitative phytochemical analysis to detect the presence of alkaloids, carbohydrates, glycosides, saponinis, phytosterols, phenols, tannins, flavonoids, proteins, aminoacids and diterpens was carried out by using the standard methods and the intensity of the coloration determines the abundance of the compound present. ${ }^{2}$

\section{RESULT AND DISCUSSION}

\section{Percentage of yield extract}

The yield of sequential extracts Aerva lanata (g) is shown in (Table 1). The amount obtained from hexane, chloroform, ethyl acetate, acetone and methanol extracts are $5.020 \mathrm{gm}, 4.080 \mathrm{gm}, 2.750 \mathrm{gm}, 1.720 \mathrm{gm}$, and 3.750 gm respectively.

\section{Anti-HIV activity of Aerva lanata root extracts}

Inhibition of HIV-RT by Aerva lanata root extracts were presented in Figure 1. Chloroform and methanol extraction shows highest inhibition of recombinant HIV-RT (91.0\% and $89.0 \%$ respectively) at $2 \mathrm{mg} / \mathrm{ml}$ concentration. Hexane, ethyl acetate and acetone extractions showed highest inhibition of HIV-RT at $2 \mathrm{mg} / \mathrm{ml}$ concentration $(86.9,85.2$ and 77.5 respectively). While control drug (AZT) showing $91.7 \%$ at $2 \mathrm{mg} / \mathrm{ml}$ concentration.

ALHE - Aerva lanata Hexane Extract

ALAE - Aerva lanata Acetone Extract

ALCE - Aerva lanata Chloroform Extract

ALME - Aerva lanata methanol Extract

ALEAE- Aerva lanata Ethyl acetate Extract 


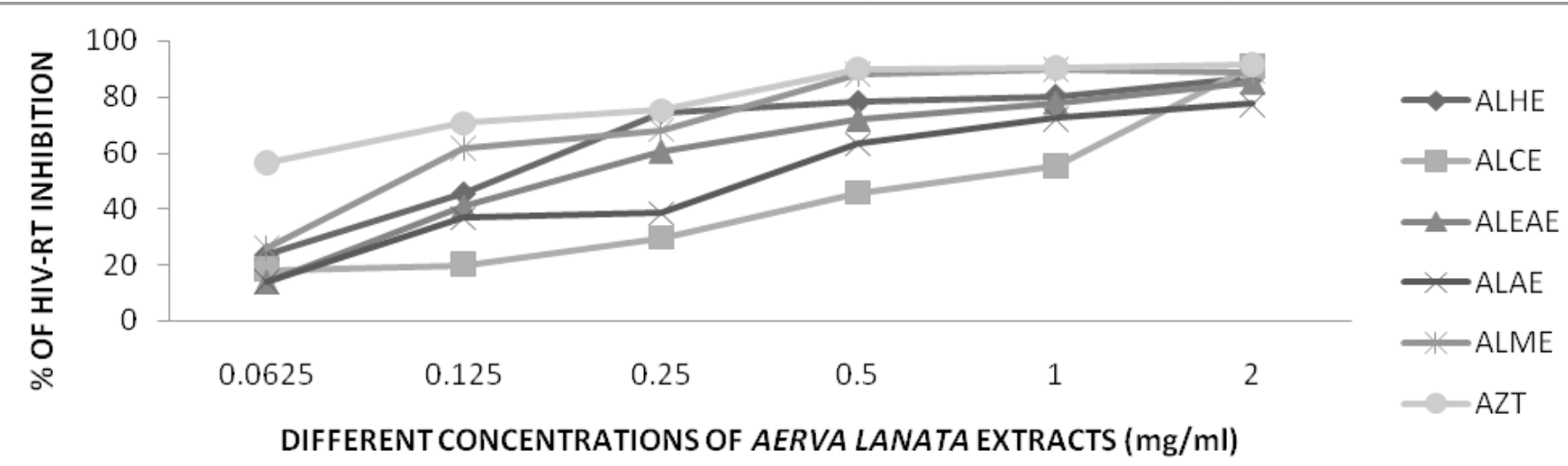

Figure 1: In vitro HIV-RT inhibitory activity of Aerva lanata root extractions

\begin{tabular}{|c|c|c|c|c|c|c|c|c|c|c|}
\hline \multirow[t]{2}{*}{ Extract name } & \multicolumn{2}{|c|}{ Solvent system I } & \multicolumn{2}{|c|}{ Solvent system II } & \multicolumn{2}{|c|}{ Solvent system III } & \multicolumn{2}{|c|}{ Solvent system IV } & \multicolumn{2}{|c|}{ Solvent system V } \\
\hline & $\begin{array}{c}\text { No. of } \\
\text { spots } \\
\text { detected }\end{array}$ & $\begin{array}{c}\mathrm{R}_{\mathrm{f}} \\
\text { Value }\end{array}$ & $\begin{array}{c}\text { No. of } \\
\text { spots } \\
\text { detected }\end{array}$ & $\begin{array}{c}\mathrm{R}_{\mathrm{f}} \\
\text { Value }\end{array}$ & $\begin{array}{c}\text { No. of } \\
\text { spots } \\
\text { detected }\end{array}$ & $\begin{array}{c}\mathrm{R}_{\mathrm{f}} \\
\text { Value }\end{array}$ & $\begin{array}{c}\text { No. of } \\
\text { spots } \\
\text { detected }\end{array}$ & $\begin{array}{c}\mathrm{R}_{\mathrm{f}} \\
\text { Value }\end{array}$ & $\begin{array}{c}\text { No. of } \\
\text { spots } \\
\text { detected }\end{array}$ & $\begin{array}{c}\mathrm{R}_{\mathrm{f}} \\
\text { Value }\end{array}$ \\
\hline \multirow{3}{*}{$\begin{array}{c}\text { Chloroform } \\
\text { extract }\end{array}$} & 2 & 0.18 & 3 & 0.10 & 2 & 0.05 & 2 & & 2 & 0.24 \\
\hline & & 0.94 & & 0.82 & & 0.90 & & 0.09 & & 0.35 \\
\hline & & & & 0.90 & & & & 0.73 & & \\
\hline
\end{tabular}

Table 3: Eluted fractions and their masses, Number of spots detected and $\mathbf{R}_{f}$ values

\begin{tabular}{cccccccc}
\hline $\begin{array}{c}\text { Compound } \\
\text { fraction }\end{array}$ & $\begin{array}{c}\text { Mass } \\
(\mathbf{g})\end{array}$ & $\begin{array}{c}\text { No. of spots } \\
\text { detected }\end{array}$ & $\mathbf{R}_{\mathrm{f}}$ values & $\begin{array}{c}\text { Compound } \\
\text { fraction }\end{array}$ & $\begin{array}{c}\text { Mass } \\
(\mathbf{g})\end{array}$ & $\begin{array}{c}\text { No. of spots } \\
\text { detected }\end{array}$ & $\mathbf{R}_{\mathrm{f}}$ values \\
\hline Fraction 1 & 0.02 & -- & Nil & Fraction 13 & 0.01 & 02 & $0.32,0.51$ \\
Fraction 2 & 0.15 & -- & Nil & Fraction 14 & 0.07 & 02 & $0.32, .051$ \\
Fraction 3 & 0.22 & 02 & $0.35,0.81$ & Fraction 15 & 0.09 & 02 & $0.32,0.51$ \\
Fraction 4 & 0.03 & 02 & $0.35,0.82$ & Fraction 16 & 0.11 & 02 & $0.32,0.50$ \\
Fraction 5 & 0.05 & 02 & $0.35,0.82$ & Fraction 17 & 0.02 & 02 & $0.32,0.51$ \\
Fraction 6 & 0.32 & 02 & $0.35, .081$ & Fraction 18 & 0.05 & 02 & $0.31,0.51$ \\
Fraction 7 & 0.14 & 02 & $0.31,0.51$ & Fraction 19 & 0.18 & 02 & $0.32,0.51$ \\
Fraction 8 & 0.11 & 02 & $0.32,0.51$ & Fraction 20 & 0.23 & 02 & $0.32,0.51$ \\
Fraction 9 & 0.01 & 02 & $0.32,0.51$ & Fraction 21 & 0.05 & 02 & $0.55,0.77$ \\
Fraction 10 & 0.04 & 02 & $0.32,0.51$ & Fraction 22 & 0.08 & 02 & $0.55,0.77$ \\
Fraction 11 & 0.13 & 02 & $0.32,0.50$ & Fraction 23 & 0.02 & 02 & $0.55,0.77$ \\
Fraction 12 & 0.03 & 02 & $0.32,0.51$ & Fraction 24 & 0.06 & 02 & $0.55,0.77$ \\
\hline
\end{tabular}

\section{AZT - Azidothymin}

\section{Thin layer chromatographic analysis}

The TLC chromatograms of the chloroform extract of $A$. lanata in different solvent systems were shown in solvent system I, 2 spots were visible with $\mathrm{R}_{\mathrm{f}}$ values 0.18 and 0.94 . In solvent system II, 3 spots were detected with $\mathrm{R}_{\mathrm{f}}$ values $0.10,0.82$ and 0.90 . In solvent system III, 2 spots were detected with $R_{f}$ values 0.05 and 0.90 . In solvent system IV, 2 spots were visible with $R_{f}$ values 0.09 and 0.78 . In solvent system $V, 2$ spots were obtained having $\mathrm{R}_{\mathrm{f}}$ of 0.24 and 0.35 (Table 2). Solvent system $\mathrm{V}$ was selected for further process of separation.

\section{Column chromatographic analysis}

The solvent system $\mathrm{V}$ used as the eluent while silica gel was used as the solid phase. A total of 24 fractions were eluted from the roots of Aerva lanata. All fractions were spotted on TLC plate and on visualized using iodine vapors and the fractions (3-8, 9-20 and 21-24) were pooled into three main categories based on their similar retardation values showed in Table 3.

F9-F20 pooled fraction shows highest anti-HIV activity. Therefore this fraction sample was processed further purification step. Above active fraction sample based on column chromatography by using solvent system chloroform and ethyl acetate in the ratio of 9:1six sub fractions 
Table 4: Eluted six fractions from F9-F20 their masses, Number of spots detected and $\mathbf{R}_{\mathrm{f}}$ values

\begin{tabular}{cccc}
\hline $\begin{array}{c}\text { Compound } \\
\text { fraction }\end{array}$ & Mass $(\mathrm{g})$ & $\begin{array}{c}\text { No. of spots } \\
\text { detected }\end{array}$ & $\mathrm{R}_{\mathrm{f}}$ values \\
\hline SF 1 & 0.10 & 02 & $0.31,077$ \\
SF 2 & 0.16 & 02 & $0.31,0.77$ \\
SF 3 & 0.14 & 02 & $0.35,0.65$ \\
SF 4 & 0.09 & 02 & $0.35,0.65$ \\
SF 5 & 0.22 & 02 & $0.32, .055$ \\
SF 6 & 0.18 & 02 & $0.32,0.55$ \\
\hline
\end{tabular}

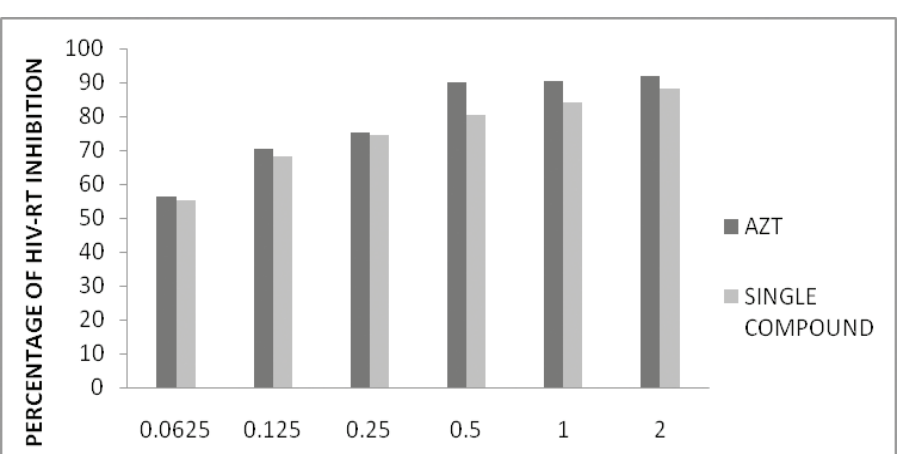

DIFFERENT CONCENTRATIONS OF SINGLE COMPOUND (FROMSF3SF4) FRACTION OF AERVA LANATA (mg/ml)

Figure 2: In vitro HIV-RT inhibitory activity of single compound (from SF3-SF4) of Aerva lanata chloroform extract

were collected (Table 4) and tested for TLC. Based on similar $\mathrm{R}_{\mathrm{f}}$ values SF1-SF2, SF3-SF4 and SF5-SF6 pooled and these pooled fractions were tested for anti-HIV activity. SF3-SF4 sub fraction showed highest anti-HIV activity. Therefore the SF3-SF4 sample was processed further purification step. On TLC SF3-SF4 sub fraction shown single spot. This determined the compound obtained was a single compound.

\section{Analysis of anti-HIV activity of active compound}

The pooled 9-20 fraction showing highest inhibition of recombinant HIV-RT $(88.2 \%)$ at $2 \mathrm{mg} / \mathrm{ml}$ concentration. The other fractions 21-24 and 3-8 are showing highest inhibition of recombinant HIV-RT (61.5 and 58.0\% respectively) at $2 \mathrm{mg} / \mathrm{ml}$ concentration. Therefore concluded that the F9-F20 fraction sample could exhibit potent activity. While control drug (AZT) showing $91.7 \%$ at $2 \mathrm{mg} / \mathrm{ml}$ concentration. In the second purification step the obtained sub fractions SF3-SF4 showing highest inhibitions of recombinant HIV-RT (89.0\%) at $2 \mathrm{mg} / \mathrm{ml}$ concentration. Therefore the sub fraction sample SF3-SF4 could exhibit potent activity against anti-HIV.

Obtained fraction sample in final purification step bring single compound and this sample shows anti-HIV activity nearly similar to used control drug (AZT) showed in Figure 2. This fraction showed 88.1\% HIV-RT inhibition at $2 \mathrm{mg} / \mathrm{ml}$, while AZT showed $91.7 \%$ at $2 \mathrm{mg} / \mathrm{ml}$ respectively.

\section{Phytochemical analysis of active compound}

In this study showed that Aerva lanata plant contained compounds of medicinal importance. This phytochemical screening and analysis revealed that the phytosterols are mainly present in the active compound. The results obtained in this study thus suggest the identified phytochemical compounds may be the bioactive constituents and this plant proving to
Table 5: Phytochemical analysis of isolated active compound of Aerva lanata root extract

\begin{tabular}{|c|c|c|}
\hline SI. No. & Phytochemicals test & Active compound \\
\hline 1 & \multicolumn{2}{|c|}{ Test for Alkaloids } \\
\hline a & Mayer's Test & - \\
\hline $\mathrm{b}$ & Wagner's Test & - \\
\hline c & Hager's Test & - \\
\hline $\mathrm{d}$ & Dragendorff's Test & - \\
\hline 2 & \multicolumn{2}{|c|}{ Test for Carbohydrates } \\
\hline a & Molisch's Test & - \\
\hline $\mathrm{b}$ & Benedict's Test & - \\
\hline c & Fehling's Test & - \\
\hline 3 & \multicolumn{2}{|c|}{ Test for Glycosides } \\
\hline a & Borntrager's Test & - \\
\hline $\mathrm{b}$ & Legal's Test & - \\
\hline 4 & \multicolumn{2}{|c|}{ Test for Saponin } \\
\hline a & Froth Test & - \\
\hline $\mathrm{b}$ & Foam Test & - \\
\hline 5 & \multicolumn{2}{|c|}{ Test for Phytosterols } \\
\hline a & Salkowski's Test & + \\
\hline $\mathrm{b}$ & Libermann Burchard's test & + \\
\hline 6 & \multicolumn{2}{|c|}{ Detection of phenols } \\
\hline a & Ferric Chloride Test & - \\
\hline 7 & \multicolumn{2}{|c|}{ Detection of tannins } \\
\hline a & Gelatin Test & - \\
\hline 8 & Detection of flavonoids & - \\
\hline a & Alkaline Reagent Test & - \\
\hline $\mathrm{b}$ & Lead acetate Test & - \\
\hline 9 & \multicolumn{2}{|c|}{ Detection of proteins and aminoacids } \\
\hline a & Xanthoproteic Test & - \\
\hline $\mathrm{b}$ & Ninhydrin Test & - \\
\hline 10 & Detection of diterpenes & - \\
\hline $\mathrm{a}$ & Copper acetate Test & - \\
\hline
\end{tabular}

be an increasingly valuable reservoir of bioactive compounds of substantial medicinal merit.

The phytosterols produce a wide spectrum of biological activities in animals and humans and are particularly considered an efficacious cholesterol-lowering agent. The anticancer activity of plant sterols has been reviewed by Awad and Fink. ${ }^{12}$ Bouic ${ }^{13}$ has reviewed the potential role of phytosterols both in the etiology as well as in the prevention of immunological diseases. Experiments in animals and cell cultures indicated that plant sterols may exert biological activities unrelated to the hypocholesterolemic effect. In experiments in vitro the substitution of cholesterol with phytosterols altered the physical properties of cell membranes, which could affect the activity of membrane-bound enzymes or signal transduction. ${ }^{14,15}$

\section{CONCLUSION}

The study showed that Aerva lanata plant contained compounds of medicinal importance. This phytochemical screening and analysis revealed that the phytosterols are mainly present in the active compound. The 
Aerva lanata root active compound can provide lead molecules which could be useful substrate for the synthesis of new broad spectrum antibiotics for the treatment of infections. So the active compound contains the phytosterols needed by the pharamaceutical companies as well as in food supplements. The qualitative analysis of these phytocompounds will be an interesting area for further purification the advanced spectroscopic studies are required for the structural elucidation, identification and characterization of the active compound would be our priority in future studies.

\section{ACKNOWLEDGEMENT}

The authors thank to Department of Zoology, Kakatiya University for providing lab facility.

\section{CONFICT OF INTERST}

Authors declare that there is no conflict of interests

regarding the publication of this paper

\section{REFERENCES}

1. UNAIDS. Report on the Global AIDS Epidemic. 2013

2. Cos $P$, Maes $L$, Vanden BD, Hermans $N$, Pieters $L$ and Vlietinck $A$. Plant substances as anti-HIV agents selected according to their putative mechanism of action. J Nat Prod. 2004;67(2):284-93. http://dx.doi.org/10.1021/np034016p.

3. De Clercq E. Current lead natural products for the chemotherapy of human immunodeficiency virus (HIV) infection. Med Res Rev. 2000;20(5):323-49. http:// dx.doi.org/10.1002/1098-1128(200009)20:5<323::AID-MED1>3.0.CO;2-A

4. Zhang $X$, Huang $N$ and Zheng YT. Advances in the study of anti-HIV natural compounds derived from traditional Chinese medicines (in Chinese). Act a Pharm Sin. 2010;45(2):141-53

5. Dos Santos-Neto LL, De Vilhena Toledo MA, Medeiros-Souza P and De Souza GA
The use of herbal medicine in Alzheimer's disease-a systematic review. Evidencebased Complementary and Alternative Medicine. 2006;3(4):441-5. http://dx.doi. org/10.1093/ecam/nel071.

6. Venkanna L and Estari Human Immunodeficiency Virus (HIV-1) reverse transcriptase inhibitory activity of Eclipta alba $(\mathrm{L})$ leaves extracts. Int J App Bio and Pham Tech. 2012;3(3):86-92

7. Joshi SP. Plant products as anti-HIV agents. Journal of Med Arom Plant Science 2002:24:1006-23.

8. Sofowra A. Medicinal Plants And traditional Medicine in Africa. Spectrum Books Ltd. 1993;191-289.

9. Amin Mir M, Sawhney SS, Jassal MMS. Qualitative and quantitative analysis of phytochemicals of Taraxacum officinale. Woodpecker Journal of Pharmacy and Pharmocology. 2013;2(1):1-5.

10. Adamson CS, Freed EO. Novel approaches to inhibiting HIV-1 replication. Antiviral Res. 2010;85(1):119-41. http://dx.doi.org/10.1016/j.antiviral.2009.09.009.

11. Rajendra PG, Estari M. Ethnobotanical survey of medicinal plants used by the tribes of Khammam district, Andhra Pradesh, India. Journal of Research in Plant Sciences. 2012;1(2):132-7.

12. Awad AB, Fink CS. Phytosterols as anticancer dietary components: evidence and mechanism of action. J Nutr. 2000;130(9):2127-30.

13. Bouic PJ. The role of phytosterols and phytosterolins in immune modulation: A review of the past 10 years. Curr Opin Clin Nutr Metab Care. 2001;4(6):471-5. http://dx.doi.org/10.1097/00075197-200111000-00001.

14. Halling KK, Slotte JP. Membrane properties of plant sterols in phospholipid bilayers as determined by differential scanning calorimetry, resonance energy transfer and detergent-induced solubilization. Biochim Biophys Acta. 2004; 1664(2):161-71. http://dx.doi.org/10.1016/j.bbamem.2004.05.006

15. Awad AB, Chen YC, Fink CS, Hennessey T. Beta-sitosterol inhibits HT-29 human colon cancer cell growth and alters membrane lipids. Anticancer Res. 1996:16(5A):2797-804.

Cite this Article: Gujjeti RP, Mamidala E. Anti-HIV Activity of Phytosterol Isolated from Aerva lanata Roots. Pharmacogn J. 2017;9(1):112-6. 